\title{
The impact of a project organisational culture and team rewarding on project performance*
}

\author{
Aljaž Stare**
}

The purpose of this paper is to identify the level of project organisational culture in Slovenian enterprises and the impact of that culture on team motivation and project execution compared with monetary rewards for finalising projects in time and within budget. The research showed a high level of project organisational culture and that only one-third of enterprises have implemented reward systems, while the results of the analysis proved that a project organisational culture along with rewards increase the motivation of team members and consequently reduces project delays and cost overruns.

Der Zweck dieses Artikels ist es, das Niveau der Projekt-Organisationskultur in slowenischen Unternehmen und die Auswirkungen dieser Kultur auf TeamMotivation und Projektabwicklung im Vergleich zu Geldprämien für pünktlich und budgetgerecht abgeschlossene Projekte zu identifizieren. Die Untersuchung zeigt eine hohe Stufe der Projekt-Organisationskultur und dass nur ein Drittel der Unternehmen Vergütungssysteme umgesetzt hat. Währenddessen zeigen die Analysenergebnisse, dass die Projekt-Organisationskultur zusammen mit Belohnungen die Motivation der Teammitglieder fördert und dadurch Projektverzögerungen und Kostenüberschreitungen reduziert.

Key words: project, organisation culture, reward, motivation

* Manuscript received: 30.06.2011, accepted 10.11.2011 (1 revision)

** Aljaž Stare, Ph.D., Senior Lecturer, Faculty of Economics, University of Ljubljana, Slovenia. Main research areas: project management, strategic management, change management. Corresponding address: aljaz.stare@ef.uni-lj.si 


\section{Introduction}

Although Slovenia is one of the most developed "transition economy countries", in the opinion of many Slovenian project stakeholders and team members the maturity level of project management in the country's enterprises is quite low. Many related weaknesses have been exposed during project management training sessions, interviews and discussions with more than 2,000 team members in the last ten years. First of all, project plans are made in haste, usually without proper risk management, with the result that improvisation is quite a common way of executing projects. The typical project organisation is a matrix, yet project managers ( $85 \%$ of them are entitled project leaders) are not "professional managers", but experts who perform many tasks and also coordinate the project. Despite the official internal rules governing how projects should be implemented, many stakeholders do not consider them. The consequences are a low level of authority enjoyed by project managers, a low level of support of line managers, and unsuitable project teams. Team members also complain that they do not receive any extra bonuses for perfectly executed projects. All of these factors could be subsumed within a project organisational culture, which forms part of a corporate culture. The majority of interviewees believed that a stronger attitude of top and line managers could increase the success of the projects within their enterprises.

Until now, unfortunately no one has carried out any empirical research to determine the real level of the mentioned cultural factors in Slovenian enterprises, or how important they truly are for project success - how much they influence team motivation and, in turn, project execution.

In response to these findings we conducted more extensive research into project management theory to examine the presented issues in theory and practice (a review of researches presented in scientific articles). We developed an overview of the most important factors of efficient project execution (Fig. 1) and focussed our research on two topics: (project) organisational culture and post-project rewards for efficient project execution.

Many researchers have revealed that money is not high on the list of motivating factors and that offering monetary rewards does not automatically ensure motivation and a high performance (Rose/Manley 2011); if an employee makes enough money to meet all their basic needs, more money matters less than other factors (Turk 2008). In addition, Slovenian salaries are on average not low compared with the majority of less developed countries. However, Slovenian employees prefer to compare their salaries with the higher ones available in nearby, more developed EU countries and this could be a reason for them complaining about not receiving any rewards for their extra work on projects. Perhaps the amount of money is not so important; rewards signal to team participants that they are valued and important contributors to the project's success (Chang et al. 2010). 
Figure 1: Important factors in effective project execution

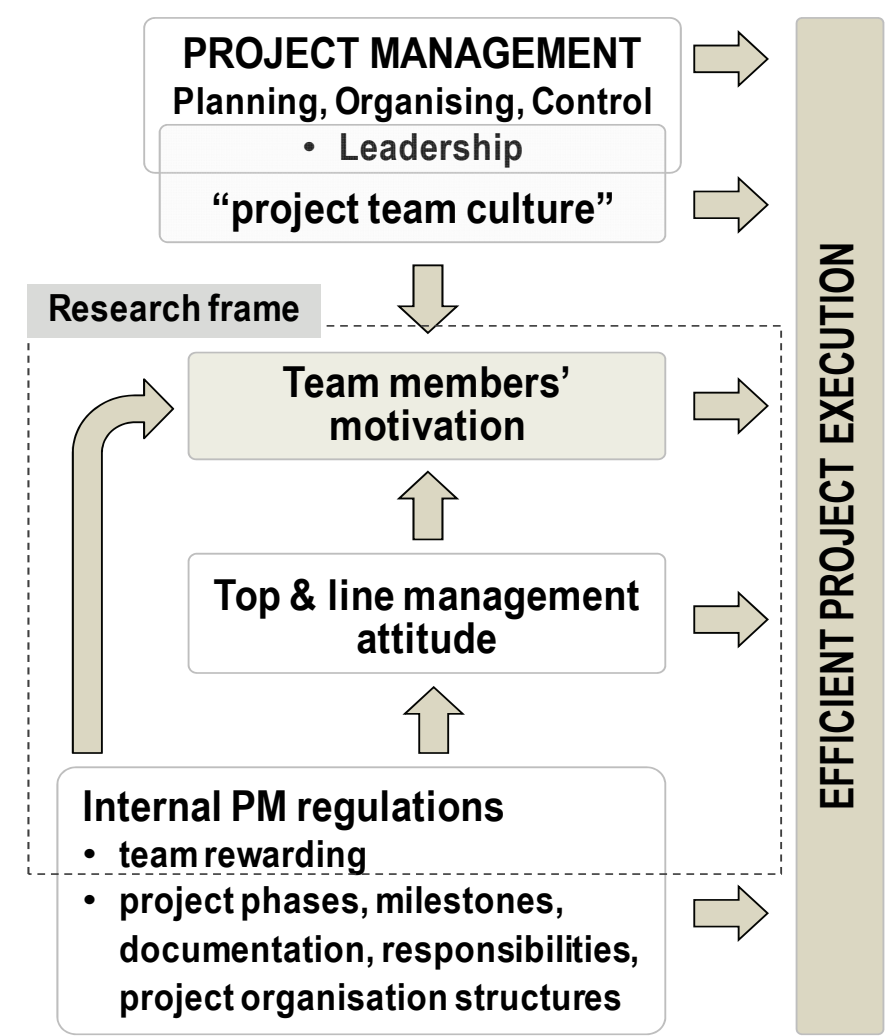

A study of the literature from the last decade shows some empirical researches have examined the motivation of the project team during execution of the project, especially regarding the role of the project manager - motivators and hygienics (Dunn 2001), motivational mistakes and the importance of individuality (Peterson 2007), stress and motivation among project team members and project managers (Gällsted 2003). Some researchers have examined the rewarding of the project team (as part of a motivation process) during execution of the project - a financial reward linked to performance (Dwivedula 2010), intrinsic \& extrinsic motivators and Adams' equity theory (Rose/Manley 2010), the direct motivation of a financial incentive (Rose/Manley 2011); the project manager's role in team motivation and rewards based on individual contributions (Schmid/Adams 2008), a risk-based pay programme (Fister Gale 2004) for rewards that motivate (Turk 2008). Yet, we found just one empirical research examining the rewarding of a project team after the project has been completed - project completion bonuses (Taylor 2010).

Many researchers have been carried out and several dimensions of organisational culture have been investigated, e.g. the organisational strategy, structure, culture, systems, behavioural patterns and processes of an organisation, thereby determining the internal environment required for project management to be successful. A study of the literature reveals three types of organisational culture impacts: 
- a corporate culture with an indirect influence - employees' involvement, consistency (a strong internal culture, a concern with shared values), mission and long-term directions, adaptability to the environment (Kuo/Kuo 2010); how decision-makers respond to ambiguity, complexity, and uncertainty (Shore 2008); organisational direction, competitiveness orientation, decision-making rationale, cross-functional integration, communication philosophy, the locus of decision-making, people management style, flexibility, philosophy about people, personal competency, process and systems support, performance management (Morrison et al. 2008; Brown 2008; Aronson/Lechler 2009); a positive work environment, management leadership, results-oriented, commercial success, technical success, customer satisfaction (Belassi et al. 2007); strong command and control capabilities or a more empowered work style (Moore 2002); very lax "we are all friends here" or very formal "buttoned down" cultures (Snedaker 2006); hierarchy, market, clan and adhocracy culture (Fong/Kwok 2009);

- a project organisational culture (a direct influence) - top and line management supporting/attitude, monitoring, prioritisation and project staffing (Kerzner 2009; Andersen et al. 2009; Young/Jordan 2008; Kearns 2007; Tinnirello 2001; Doll 1985); the organisational policies, procedures, rules, formal and informal roles (Cleland 1999); support of departments in the pursuit of project goals, employee commitment to the project goals in the context of balancing them with other, potentially competing goals, project planning - the way work is estimated or how resources are assigned to projects, the performance of project teams - how managers evaluate it and how they view the outcomes of projects (Pinto 2010); and

- the "subculture" of the project team (a direct influence) - effective communications, co-operation, trust and teamwork (Kerzner 2001), a willingness to share ideas and problems among team members, social activities of the team, calling team members by first names or nicknames, the level of formality within the team (Cleland 1999).

The latest researches around the world have mainly investigated the influence of the organisational culture of the base organisation (corporate culture) on projects. However, our research focuses more on the second viewpoint of organisational culture - top and line management's attitudes, and some other factors connected with managers' attitudes. To our knowledge, such research has not been undertaken in the last decade, especially in countries labelled "transition economy countries" in the 1990s, where the project management profession (in our view) has not been completely implemented, and where improvisation exerts a relatively big influence on work performance.

Therefore, the goals of the research presented in this article were to identify: 
- the level of project organisational culture in Slovenian enterprises;

- which types of monetary rewards are available in Slovenian enterprises, the percentage of enterprises where project teams are rewarded after the project has been finalised; and which reward types are the most common;

- the impact of each type of reward and cultural factors on efficient project execution; and

- whether efficient project execution depends more on the organisational culture or on financial rewarding.

This paper is organised in four sections. After the introduction we proceed with a brief overview of the literature on project organisational culture, motivation and team rewarding. In the next section we present the empirical research we conducted in Slovenian enterprises - the research method, the findings of the research, the analysed impacts of the researched factors on project performance, and a discussion of the results of the analysis. In the conclusion we outline the contribution to science and practice and suggest further avenues for research.

\section{Literature review}

\section{The influence of researched topics on project success/failure}

Scientists from the project management field have identified many causes of project failures. Failure or success can be defined in two ways. First, there is the traditional criterion of success - project execution within time, cost and quality constraints. The second criterion is more business-oriented - customer satisfaction, subsequent operations, financial success, technical excellence, consistency with the strategy, ethical, safe, health-hazardous and environmentally-friendly product of the project, raising the company's reputation, employee satisfaction etc. (Kerzner, 2004; Lock, 2002; Turner \& Simister, 2000). In our research we used the traditional criteria, also termed efficiency (efficient project execution means spending less money in a shorter time) because it is directly linked to the project stakeholders' behaviour during the project execution phase, while the revenue side of the project can depend on many people who were never members of the project team under the project manager's authority.

The CHAOS report prepared by the Standish Group in 2004 (Brandon, 2006) lists the following major causes of IT project failure: a lack of end-use involvement; a lack of executive support; poor project management and/or planning; an unclear business justification; and problems with requirements, scope, methodology and estimation.

Many others researches have shown that the causes of project failure can be broken up into three groups (summarised by Shauchenka, 2011; Brandon, 2006; Wysocki, 2004; whyprojectsfailbook.com; www.projectsmart.co.uk): 
- management of projects - poor planning, a lack of clear objectives or scope, poor communication, too much infighting and disputes, a failure to recognise warning signs, mistakes that trigger rework, inadequate co-ordination of resources, poor quality control;

- project organisational culture - a lack of management support, an unclear definition of roles and responsibilities, poor methodology (unclear or not enforced), competing priorities, a lack of resources (money and skilled people), a key staff member is pulled off the project; and

- client and contractor behaviour - scope and specifications changes, a lack of timely approvals, a delay in funding, defective materials, and vendors that do not deliver on time.

As we can see, almost every research found that a lack of (top/executive and line) management support is one of the most crucial factors of project success. Wysocki (2004) affirms that this is the single-most important reason for project success and that its absence is the main reason projects fail.

We can also state that all the other factors could be some kind of project culture indicators. The poor planning or management of projects as a whole can indicate a low level of project management knowledge, which may be a consequence of a poor project culture - perhaps executives cannot see the usefulness of wellqualified project managers and do not support any special trainings. Another culture indicator that influences poor project management could be poor knowledge sharing between project stakeholders in the enterprise.

In last 20 years only a few national quantitative surveys in the project management field have been undertaken in Slovenia. Unfortunately, they were all oriented to an assessment of the level of project management maturity. None of them verified the correlations and regression factors to determine the influence of the measured indicators on a project's success.

Lukin and Stivan conducted relatively similar researches. Lukin's study in 2000 included 148 respondents, while Stivan's in 2003 included 72, yet he only surveyed IT projects. Half of Lukin's and 35\% of Stivan's respondents had no project management training, which could be one of the indicators of a poor project culture. The second indicator was the responsibilities and competencies of project managers: $13.5 \%$ of project managers did not plan projects; only $38 \%$ of them assigned people to the project team (IT: 19\%), while only $61 \%$ estimated the costs (IT: $50 \%$ ). In 18\% of enterprises they did not schedule IT projects! Both authors also surveyed the level of executive management support: $2 \%$ of managers had no management support (IT: $3 \%$ ), $27 \%$ only "verbal" (without real actions; IT: $22 \%$ ), while $64 \%$ of managers really supported projects (IT: $72 \%$ ). The competencies and work of project managers were scored 3.5 (out of 5), and $62 \%$ of projects were executed within line organisation. The 
motivation of the project teams was relatively low (the average estimation was 3.1 out of 5 in Lukin's research, and 3.2 in Stivan's).

Suštersic (2002) research into project risk management included 58 respondents. The research showed that $83 \%$ of the included enterprises manage risks, yet only $34 \%$ responded that they manage risks systematically. This could be a project culture indicator, such as the percentage of enterprises that planned costs at the beginning of the project - only 38\% (71\% had a defined budget).

The latest research was made by Palcic in 2010 and included 265 respondents. The author measured the level of client satisfaction with project results, project execution within time and cost constraints, and financial success. Respondents used a six-level Likert's scale to estimate indicators. Project quality was on average given a score of 4.83 , execution within budget 4.63 and before deadline 4.26 (out of 6).

In summary, a low project organisational culture has been proven to be one of the main causes of project failure; however, no research has proven this statement in Slovenia. Researchers have measured the support of executive management, yet no one has examined the influence of support on project execution efficiency. On the other hand, we did not find any indication that the absence of financial rewards could cause project failure and there has been no research in that field in Slovenia so far.

\section{Project organisational culture}

\section{Organisational (corporate) culture}

Organisational culture is one of the most influential dimensions of the work climate and consecutively the main driving force of a business. It is reflected in the way tasks are realised, goals are set and in how people are guided toward the achievement of goals. Culture affects decision-making, thinking, feeling and the response to opportunities and threats. It also affects how people are chosen for a particular task, which affects performances and decision taking. Culture is rooted in people and subconsciously influences their behaviour - it affects their performance and vice versa - the manner of these factors affects the culture. Informally, such culture can be described as follows: "That's the way we do it!" (Lipicnik 1993) or "The way things are done around here" (Lewis 1995). Culture is the different philosophies and approaches to doing work within an organisation (Moore 2002).

Organisational culture has a number of underlying factors - it is formed by a set of values, beliefs, assumptions, common understandings, expectations, attitudes, behaviours, thinking, norms and traditions of the people in the company (Davidson 2000; Yazici 2009; Mobley in Kuo/Kuo 2010; Hooijberg/Petrock in Fong/Kwok 2009), and is also affected by ethnic cultures (Lewis 1995). Culture also represents a person's attitudes arising out of their 
professional, religious, class, educational, gender, age and other backgrounds and people's capacity for learning and transmitting knowledge (Turner 2000; PMI 1987; Wideman 2004). It can be described by three levels: artefacts, espoused values, and basic, underlying assumptions (Eskerod/Skriver 2007).

Schein (1988) characterises culture as consisting of three levels: the most visible level is behaviour and artefacts (they describe what a group is doing, but not why), the next level is the values that underlie and to a large extent determine behaviour (but they are not directly observable), while the third and deepest level involves assumptions and beliefs. Schein believes that familiarity with the last two indicators helps us understand culture, yet it is very hard to research them (www.au.af.mil).

All of the mentioned dimensions of culture are shared by all members of an enterprise and guide how employees get work done. The organisational context of a culture serves as a foundation for the methods of operation, an organisation's management system as well as a set of management practices and behaviours that both exemplify and reinforce those basic principles (Davidson, 2000).

\section{Project culture}

Project culture is one of the most influential factors of successful project implementation in enterprises and is part of the overall organisational culture (Skarabot 1998). Project culture is the general attitude to projects within the business. Most projects do not operate in isolation; they have to operate within a business environment that should be complementary to the requirements of good project management. The culture affects strategic planning and implementation, project management, and everything else (Cleland 1999).

Pinto (2010) reveals four ways organisational culture can affect project management. First, it affects how departments are expected to interact and support each other in the pursuit of project goals. Second, the culture influences the level of employee commitment to the goals of the project in the context of balancing them with other, potentially competing goals. Third, the organisational culture influences project planning processes such as the way work is estimated or how resources are assigned to projects. Finally, the culture affects how managers evaluate the performance of project teams and how they view projects' outcomes.

The most important issue is top and senior management support (Kerzner 2001; Tinnirello 2001). The lack of top management involvement is the primary challenge project managers felt was most deserving of their attention (Simonsen 2007). Young and Jordan (2008) provide the following definition of top management support: CEO and other senior managers devote time to review plans, follow up on results and facilitate management problems. 
The relationship between project management and senior management is equally important. A good relationship with executive management, specifically the executive sponsor, includes these factors (Kerzner 2001):

- The project manager is empowered to make project-related decisions. This is done through the decentralisation of authority and decisionmaking.

- The sponsor is briefed periodically while maintaining a hands-off, but available, position. The project manager (and other project personnel) is encouraged to present recommendations and alternatives rather than just problems.

- Exactly what needs to be included in a meaningful executive status report has been formulated.

- A policy is in place that calls for periodic briefings.

Perhaps the most important task of top management regarding projects is to develop a mutually agreed priority scheme for project screening and selection (Doll 1985). That author focused on top management's involvement in projects to develop the management information system, but in our experience this issue is important across all kinds of projects. Top management decides whether projects will be executed, they establish the priorities, and they define who the project sponsors are.

Co-operative cultures require effective management support at all levels and the interface between project management and line management is critical. A matrix organisation is particularly important, where responsibility for the project is shared between the project manager and line managers (Levine 2002). Effective relationships with line management are based on the following factors (Kerzner 2001):

- Project managers and line managers are together accountable for the successful completion of a project. Line managers must keep their promises to the project managers.

- Project managers negotiate with line managers for the accomplishment of deliverables rather than for specific talent. Project managers can request specific talent, but the final decision on staffing belongs to the line manager.

- Line managers trust their employees enough to empower those employees to make decisions related to their specific functional area without continuously having to run back to their line manager.

- If a line manager is unable to keep a promise they have made regarding a project, then the project manager must do everything possible to help the line manager develop alternative plans. 
- Both the project and line manager can develop a mutually agreeable project culture and working relationship. There are four typical cultures (Kerzner/Saladis 2009):

- co-operative - based on trust, communication, teamwork, and cooperation;

- competitive - each one tries to advance at the expense of the other;

- isolated - the functional unit creates its own culture, and the project manager must manage work according to that culture or risk alienating the line manager and the functional group; and

- fragmented - this appears in multinational projects and virtual teams where the manager has to co-ordinate more dislocated teams with different project cultures.

Another important issue of project culture is the organisational policies, procedures, rules and strategies; the tools and principles of project work in the enterprise (Cleland 1999; Kerzner 2001). Its "project management methodology" must not simply be theoretical and found solely on pieces of paper; it must be converted into a world-class methodology in the way in which the corporate culture executes the methodology. Companies which excel in project management have co-operative cultures where the entire organisation supports a singular methodology.

People often resist following a standardised process (Tinnirello 2001). This is especially difficult in an environment where people have not been educated in the methods, and the project has been carried out for many years in an ad hoc environment. Employees also fear that such a process stifles creativity and the empowerment of people. However, standardisation enables the efficient and effective execution of project activities through consistency; it enables the better integration of activities because team members can see the interrelationships of their work with that of others; and third, it reduces rework because it enables the use of output developed in earlier projects. Regardless of how the organisation obtains a standardised process, the key is to develop or adopt one that people can agree on and that it is compatible with the company's culture.

According to Skarabot (1994), project organisational culture is best exemplified by the position of the project manager in the company and the attitude of employees to the project. The project manager's authority should depend on the level of the project; the manager of a project with a high priority should have similar competencies as line managers and should be paid as a manager. However, the informal role of a project manager could be even more important (Cleland 1999).

As we showed before, Schein stated that visible indicators of culture (artefacts and behaviour) reveal what a group is doing, but not why. In the same way the presented authors explain project management organisational culture - with the 
behaviour of project stakeholders, yet they do not explain (or research) which values, assumptions etc., force them to behave as they do. Based on those findings our research was also focused on visible indicators of culture - the project stakeholders' behaviour (Table 1).

\section{Table 1: Project cultural indicators included in the research}

\begin{tabular}{|l|l|}
\hline $\begin{array}{l}\text { Cultural } \\
\text { dimension }\end{array}$ & Definition \\
\hline $\begin{array}{l}\text { Top management } \\
\text { attitude }\end{array}$ & $\begin{array}{l}\text { Plan the review, project monitoring and evaluation of the } \\
\text { performance, problem facilitating, the role of project } \\
\text { sponsors, rewarding the team after the project closes } \\
\text { (Prioritising projects) }\end{array}$ \\
\hline $\begin{array}{l}\text { Clear priorities of } \\
\text { projects }\end{array}$ & $\begin{array}{l}\text { A definition of the priorities (business case, feasibility } \\
\text { study...), team recruitment, sponsor selection, solving } \\
\text { bottlenecks }\end{array}$ \\
\hline $\begin{array}{l}\text { Line management } \\
\text { attitude }\end{array}$ & $\begin{array}{l}\text { Supporting projects, staffing the project team (allocation } \\
\text { of suitable and available employees), expert adviser, } \\
\text { respecting project priorities }\end{array}$ \\
\hline $\begin{array}{l}\text { Projects follow the } \\
\text { internal regulations }\end{array}$ & $\begin{array}{l}\text { Process, decision-making, responsibilities and } \\
\text { competencies, typical phases and milestones, documents }\end{array}$ \\
\hline $\begin{array}{l}\text { Respect of the } \\
\text { project manager's } \\
\text { formal authority }\end{array}$ & $\begin{array}{l}\text { Official vs. real competencies, formal and informal } \\
\text { roles, position in the hierarchy, possibility of motivating } \\
\text { project team members }\end{array}$ \\
\hline
\end{tabular}

Based on the theory presented above, we postulate:

Hypothesis 1: The behaviour and artefacts of project stakeholders, especially top and line managers (a visible part of project organisational culture), increases the team members' motivation.

\section{Rewarding project team members}

Money can motivate but it is not high on the list of motivating factors (Turk 2008). Shared recognition for the contributing team members of a successful project is often far more important than cash bonuses (Forsberg et al. 2005), financial rewards are nice but knowing that others appreciate your work is the most meaningful thing for most people (Heerkens 2002). As we can see from these claims, financial rewards should not have a large influence on team motivation, yet some impact still exists.

According to Deci, motivation factors are interpreted as being either intrinsic or extrinsic. The first refers to internal needs such as honour, pride, decency and satisfaction. Extrinsic motivation refers to motivation induced by external needs, 
most importantly by direct or indirect monetary compensation and incentives (Rose/Manley 2010, Hars/Ou 2002). However, not only monetary rewards signal to team participants that they are valued and important contributors to the team's success (Chang et al. 2010). Authors quote Handy and Dessler who stated that the degree of effort invested in the activity depends on the receipt of rewards commensurate with the effort - individuals choose whether they become involved and determine how much effort they will invest to maximise their potential benefits.

Rose and Manley (2011) examined four case projects and found that the offer of a financial incentive directly motivated the majority of rewarded participants even though the rewards varied across the case projects in terms of financial strength, goals, distribution and measurement processes. However, they also found that offering a financial incentive does not automatically ensure project motivation and performance. The case projects revealed a wide range of motivation drivers influencing motivation and the simple presence of a financial incentive may not be a sufficient condition for an improved performance, nor even a necessary condition. Lewis also claimed that rewards create compliance and not commitment (Schmid/Adams 2008).

Rewards have to be linked to performance. Sarin and Mahajan (2001) examined the effect of rewards on cross-functional product development teams. They found that for long and complex projects outcome-based rewards have a positive effect on performance, while process-based rewards have a negative effect. Fister Gale (2004) examined pay systems (skills-, knowledge- and riskbased pay models). A typical risk-based pay model means that some share of the project manager's total salary depends on meeting the project's objectives. Project team members can be rewarded in the same way if the project is efficiently executed.

The reward must be great enough to motivate people (based on the effort/cost to achieve) and to offset opportunistic behaviour (too low a reward for hard work may be regarded more as an insult than a reward, Parker et al. 2000); however, rewards should also follow the guidelines of equity theory (Schmid/Adams 2008). The theory explains the motivation of an employee as being relative to the outcomes achieved vs. the efforts exerted (Adams in Dwivedula/Bredillet 2010). If the size of a financial reward offered and distributed does not fairly match the desired performance level, it can fail to motivate (Rose/Manley 2010). Team performance is also affected by how rewards are distributed among members of the team. Equal rewards are more appropriate when the level of task interdependence is high (Sarin/Mahajan 2001); otherwise, the manager must decide whether rewards should be given to team members according to their individual contributions (Schmid/Adams 2008).

Taylor (2010) believes that project team members are typically rewarded by a cash payment on the successful completion of a project or when a significant 
milestone has been reached of a large, lengthy project. Payments may be fixed amounts based on a specific team role but can also be a percentage of the annual base salary or other formula-based calculations. Some people are motivated by indirect future rewards or future returns - by increasing their marketability and skill base or by selling related products and services (Hars/Ou 2002).

Based on the theoretical research of motivation factors, we developed the second hypothesis:

Hypothesis 2: When monetary rewards for efficient project execution are implemented in the enterprise, the project team members' motivation is higher. Monetary rewards are a more important motivation factor than project organisational culture.

We assumed that both a project organisational culture and rewards provide for the more efficient execution of a project. This represents our third hypothesis:

Hypothesis 3: The motivation of team members, project organisational culture and expected monetary rewards for team members provide for the more efficient execution of a project.

Figure 2: The research construct

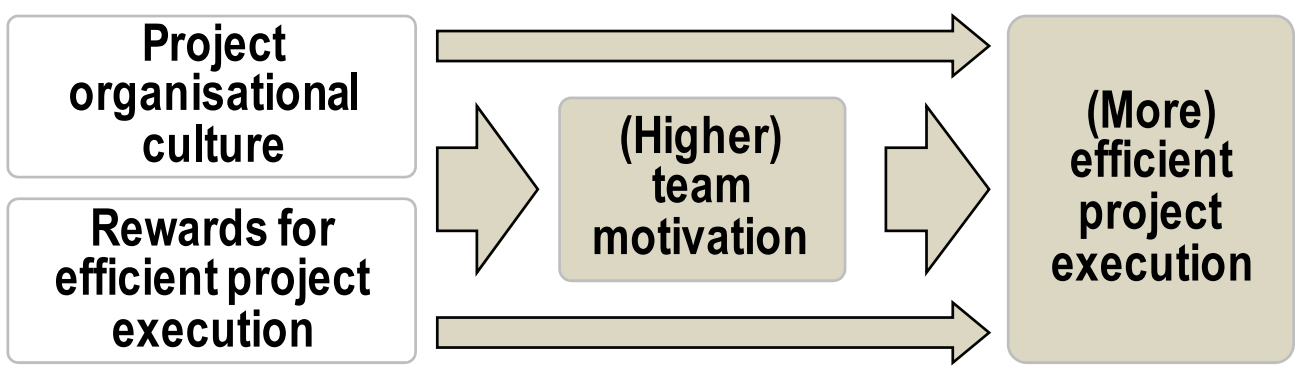

\section{Empirical research}

\section{Research design}

Web-based questionnaire was used for the purpose of testing the hypotheses. 950 respondents (project managers, team members and other stakeholders) from various companies and the public sector were invited to participate in the survey. The criterion for selecting the participants was their project management knowledge through which we ensured an understanding of critical issues, quality responses and, consequently, better survey outcomes. Therefore, members of the Slovenian Association for Project Management, along with those who had attended Slovenian conferences on project management in the last decade, obtained various project management certificates, and been trained in the project management field at various institutions were invited to participate in the survey. The results were collected in a web questionnaire and we received 137 completed questionnaires. 
Demographics of the respondents:

- female: $25 \%$, male: $75 \%$;

- average age: 40 years ( $42 \%$ of the respondents were between 30 and $40)$;

- the majority of respondents were university-educated (87\%), 26\% of them had an MSc or a $\mathrm{PhD}$;

- the majority had some kind of project management training (96\%); $33 \%$ had taken a course at the faculty, $16 \%$ had graduated in the field of project management, $11 \%$ had obtained an international certificate; and

- average years of experience: 10 years of project work, 6 years as a project manager.

We present the type and size of the enterprises involved in the study in Figure 3.

Figure 3: Enterprises involved in the study

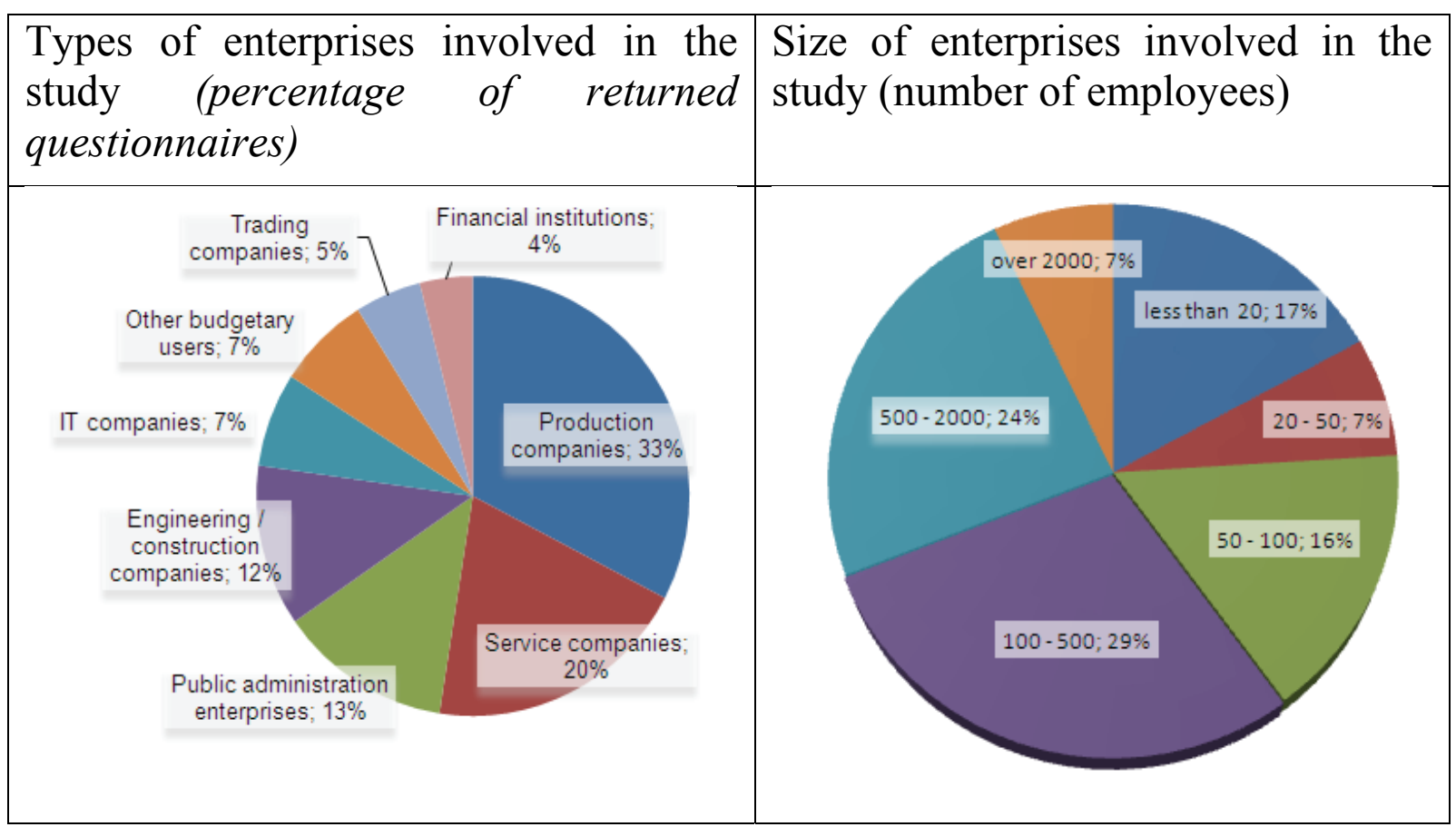

The first variable, used for testing of all the hypotheses, was the level of team motivation. It presents a dependent variable for testing the first two hypotheses, and an independent variable for testing the third hypothesis. A five-level Likert's scale was used to estimate team motivation - the respondents were asked to estimate the level of the project team members' motivation in their enterprise, from 1 (very low) to 5 (very high).

Since the third hypothesis includes a test of the factors of effective project execution (motivation of team members, behaviour of project stakeholders, and monetary rewards), we defined two efficiency indicators representing the dependent variables: project delay and cost overrun. We used the ratio (\%) 
between the baseline and the actual indicators (indicated at the end of the project). The respondents had to estimate the average final deviations of those two indicators for all projects within their enterprises.

The independent variables, derived from the construct, were cultural factors (Table 1) and the use of different types of rewards in the enterprises. The independent variables are presented in Figure 4.

Figure 4: The research model and measured variables
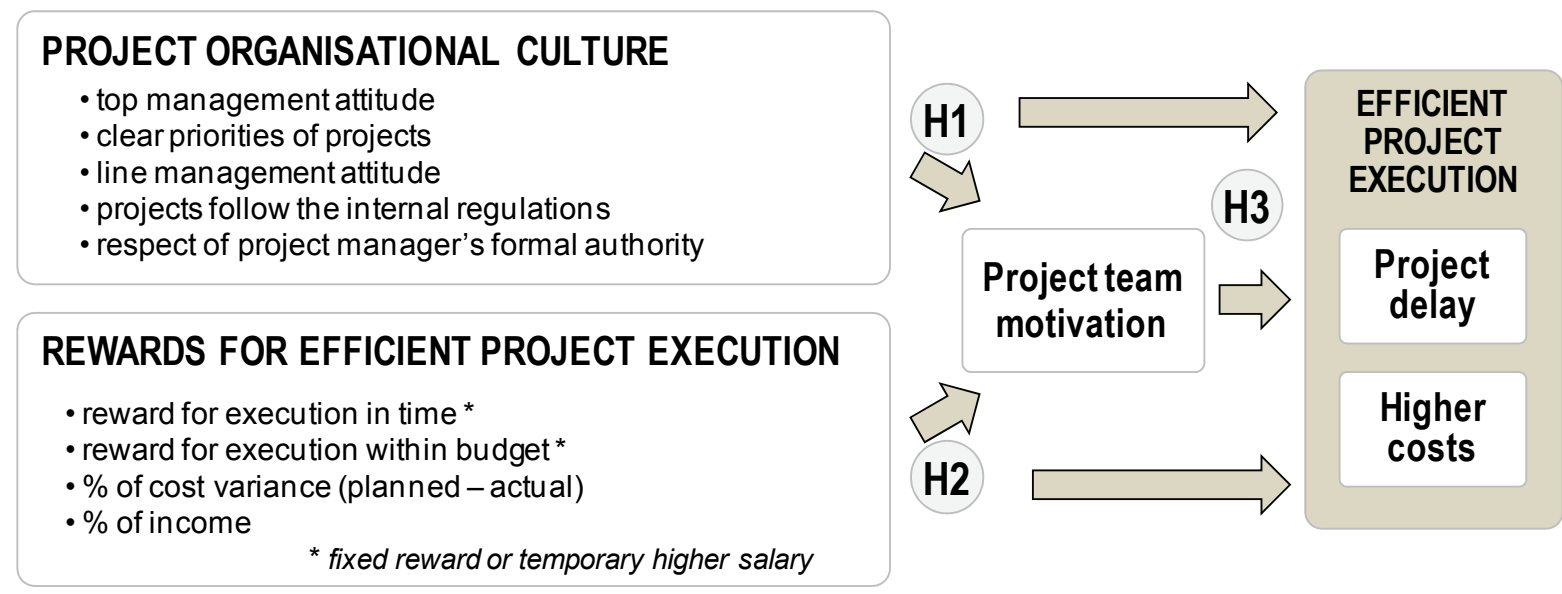

First, we examined the level of the cultural factors. We asked the respondents to estimate five indicators of the project organisational culture using a five-level Likert scale:

- Top management attitude: 1 - they have no interest in projects, 5 regular communication and monitoring;

- Priorities of projects: 1 - priorities are not defined, 5 - each project has a priority to be considered;

- Line management attitude: 1 - a negative attitude, 5 - they support projects;

- Project management regulations: 1 - regulations are ignored, 5 strictly followed;

- Project manager's authority: 1 - competencies are only on paper, 5 - formal competencies are put into force.

The respondents then had to define if and what type of reward for efficient project execution has been implemented in their enterprise (we made a list of potential rewards (Fig.4) and offered them the possibility to define a reward which was not listed). For the correlation analysis we used binary independent variables for rewarding (present $=1$, no $=0)$.

To test the hypotheses and the developed model we analysed the acquired data with a multivariate analysis, specifically by determining the correlations and regressions. The SPSS software was used for the analysis.

With the correlation analysis we verified whether: 
- a higher level of particular organisational culture indicators increases (or decreases) the project team's motivation and influences effective project implementation;

- the existence of monetary rewards increases (or decreases) the project team's motivation and which type of reward proved to be the most efficient;

- any correlations exist among project organisational culture factors and rewards; and

- a higher level of team motivation increases the efficiency of the project team and consequently decreases project delays and cost overruns.

To determine the impact of the presence of independent variables in the model, we calculated Pearson's correlation coefficient between: a) the levels of cultural factors (1-5); and b) the binary independent variables for rewarding (1/0); along with: a) the level of team motivation (1-5); and b) the effectiveness of project execution (project performance).

The integrated model and its interacting parts were checked with a multiple linear regression. However, to verify the hypothesis that individual parts of the model (a project organisational culture, rewards for efficient project execution) provide for the more efficient execution of a project (H3), every part was examined by a multiple linear regression - first we examined the correlation, the impact factor and the significance on team motivation, then on project performance.

\section{Results and discussion}

First we present the measured indicators of project execution efficiency (the dependent variables): project delay and cost overrun. The research showed that in almost $90 \%$ of Slovenian enterprises projects are executed with delays and overbudget costs (Table 1). On average, projects are prolonged in time by $20.8 \%$, while costs are $14.5 \%$ overbudget. Regarding the findings from the interviews presented in the Introduction, the discovered indicators of nonefficient project execution in Slovenian enterprises did not come as a surprise. 
Table 2: Project delays and overbudget projects in Slovenian enterprises

\begin{tabular}{|l|l|l|}
\hline & Time & Cost \\
\hline $\begin{array}{l}\text { Number of enterprises } \\
\text { indicating a delay/overbudget }\end{array}$ & $\begin{array}{l}122 \\
(89 \%)\end{array}$ & $\begin{array}{l}119 \\
(87 \%)\end{array}$ \\
\hline Average delay/overbudget & $20.8 \%$ & $14.5 \%$ \\
\hline Standard deviation & 19.2 & 14.2 \\
\hline $\begin{array}{l}\text { Enterprises with a } \\
\text { delay/overbudget over 50\% }\end{array}$ & $\begin{array}{l}26 \\
(19 \%)\end{array}$ & $\begin{array}{l}13 \\
(9 \%)\end{array}$ \\
\hline $\begin{array}{l}\text { Enterprises with a } \\
\text { delay/overbudget over 20\% }\end{array}$ & $\begin{array}{l}67 \\
(49 \%)\end{array}$ & $\begin{array}{l}45 \\
(33 \%)\end{array}$ \\
\hline
\end{tabular}

The level of project cultural organisational dimensions in Slovenian enterprises is relatively high, on average above 3.5 (values ranging from 1 to 5, Figure 5), which was relatively surprising compared to the low level of efficient project execution shown in Table 2.

Figure 5: Level of dimensions of the project organisational culture (with standard deviations)

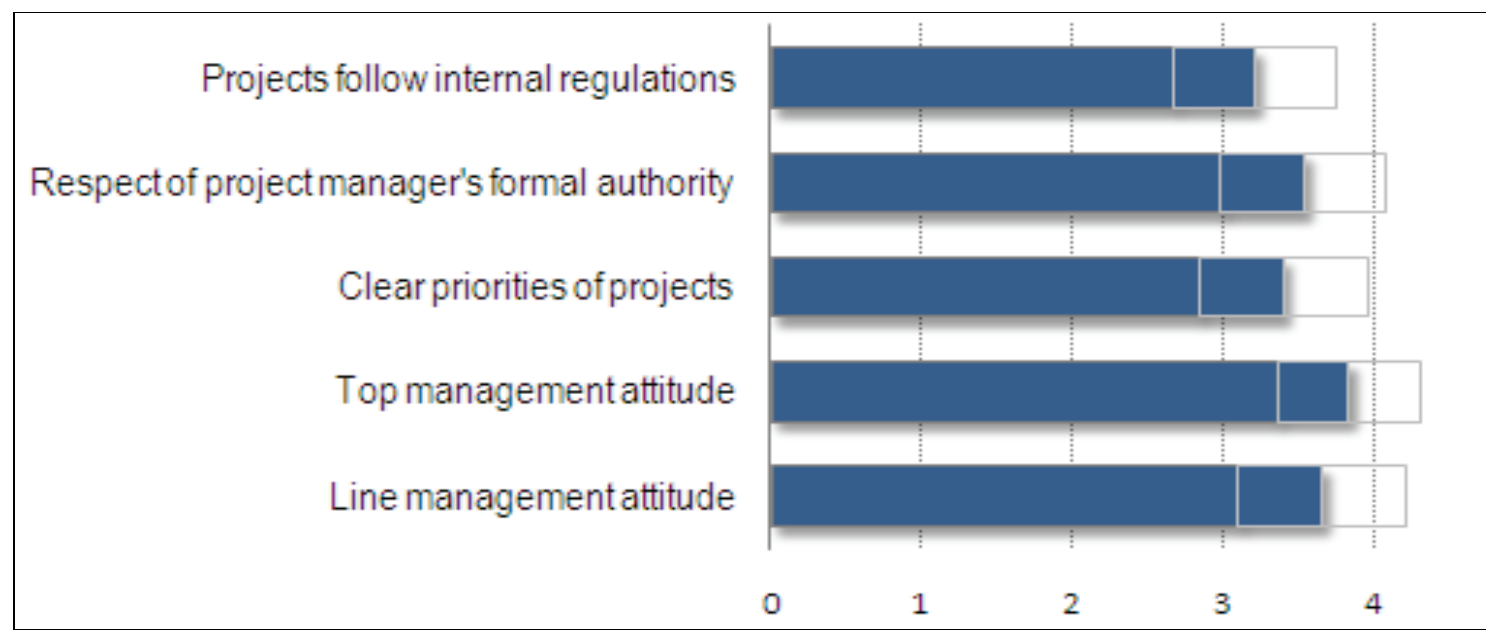

Different types of rewards have been implemented in Slovenian enterprises (Figure 6), even though 63\% of respondents indicated that they did not have any "project reward system" in the enterprise. 
Figure 6: Type of rewards most often used by the enterprises

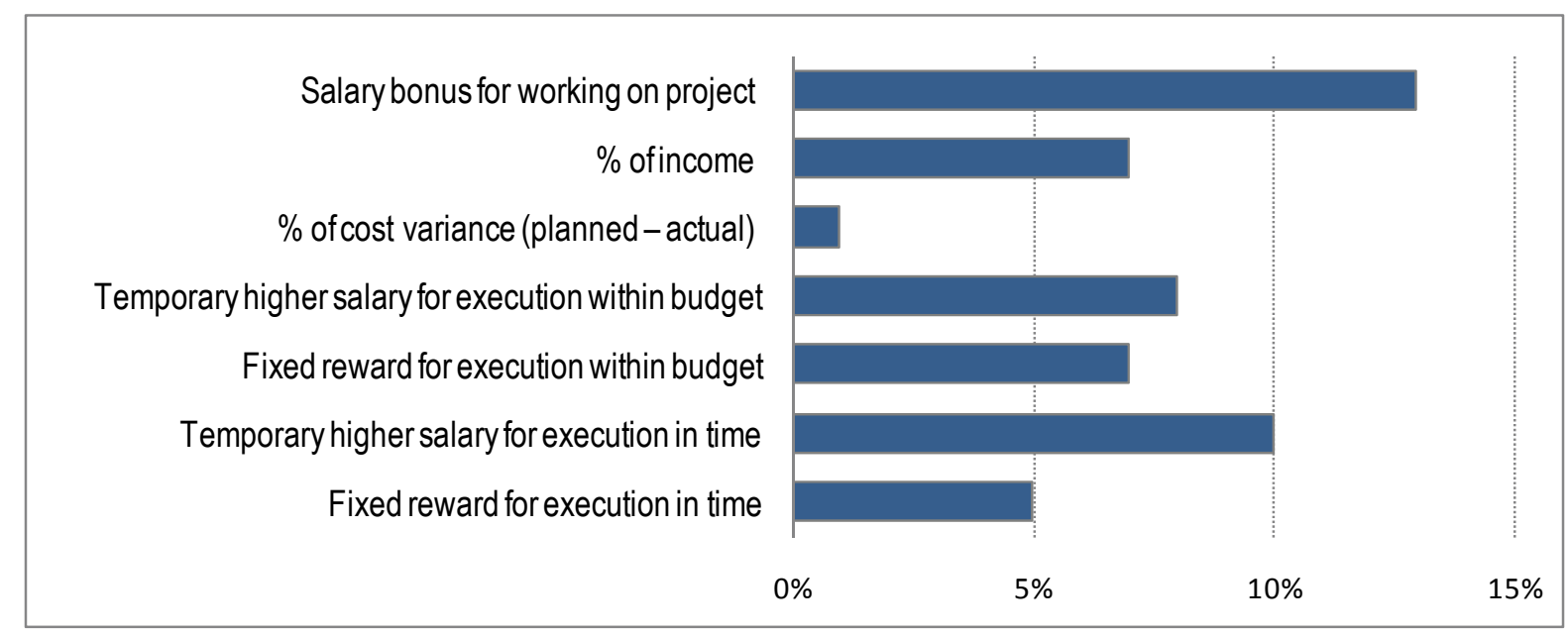

Note: The share of enterprises that usually use a particular type of reward

The correlation analysis of the organisational cultural factors shows the high level of importance of the selected organisational culture indicators on team motivation (Figure 7) and project performance (Figure 8). All of the measured variables were highly correlated with team motivation ( $\rho$ from 0.447 to 0.596 , Sig. $=0.000$; the details are presented in the appendix). All of the measured culture indicators were also correlated with the efficiency indicators (project delay and cost overrun), which shows the high impact of organisational culture on efficient project execution. All the correlation factors were negative, proving that the higher the level of culture, the smaller the project delay and cost overrun.

Rewards (any kind) were correlated with team motivation $(\rho=0.342)$ and hence with the three types of rewards. However, the correlation analysis showed that monetary rewards were no directly correlated with efficient execution.

The correlation analysis also showed a correlation among particular project culture factors (top and line management attitude) and the implemented rewards - apparently, rewards are mainly implemented in enterprises with a high level of project culture (Fig. 7). 
Figure 7: Correlations among the cultural dimensions, organisational structure and effective project execution

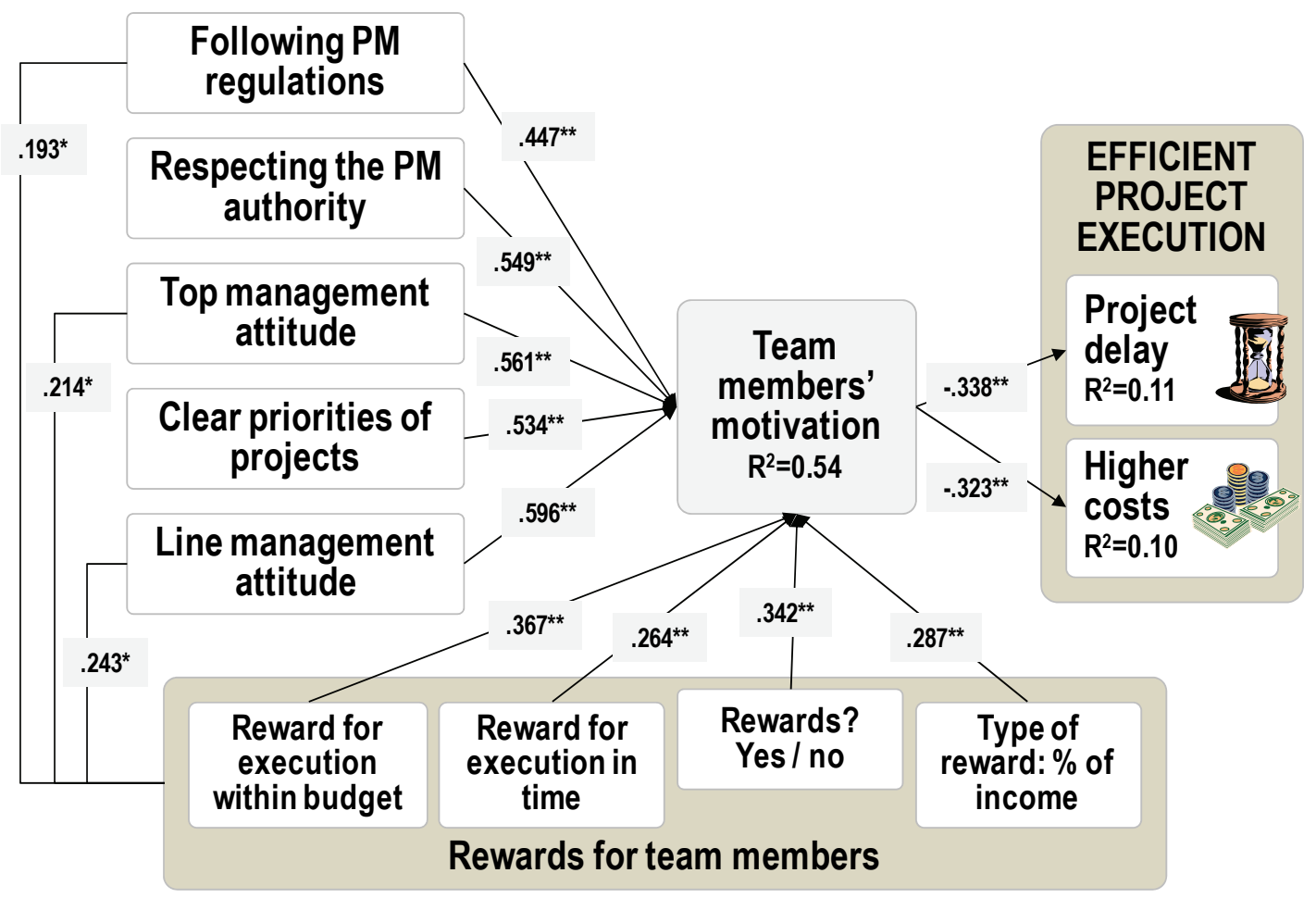

The multiple linear regressions showed that both a project organisational culture and rewards have a prominent impact on team motivation (Fig. 8; Impact via motivation, left part), and team motivation has prominent impact on effective project execution - decreases project delays and cost overruns (Fig. 8; Impact via motivation, right part). However, only the organisational culture also has a direct impact on the project execution (Fig. 8, Direct impact), while rewards have only indirect impact on the project performance via team members' motivation (Fig. 8; Impact via motivation, right part). The details of regression analyses are presented in the appendix. 
Figure 8: Impact of cultural dimensions and rewards on effective project execution

\section{Impact via motivation}

\begin{tabular}{|c|c|c|c|c|c|c|c|c|}
\hline \multirow{2}{*}{$\begin{array}{c}\text { Project } \\
\text { organisational } \\
\text { culture }\end{array}$} & $R$ & RSquare & Sig. & \multirow{3}{*}{$\begin{array}{c}\text { Project } \\
\text { team } \\
\text { motivation }\end{array}$} & $\mathrm{R}$ & RSquare & Sig. & \multirow{2}{*}{$\begin{array}{c}\text { Project } \\
\text { delay }\end{array}$} \\
\hline & .710 & .504 & .000 & & .338 & .114 & .000 & \\
\hline \multirow{2}{*}{$\begin{array}{l}\text { Rewards for } \\
\text { efficient project }\end{array}$} & $R$ & R Square & Siq. & & $\mathrm{R}$ & RSquare & Sig. & \multirow{2}{*}{$\begin{array}{l}\text { Higher } \\
\text { costs }\end{array}$} \\
\hline & .460 & .212 & .000 & & .323 & .104 & .001 & \\
\hline
\end{tabular}

\section{Direct impact}
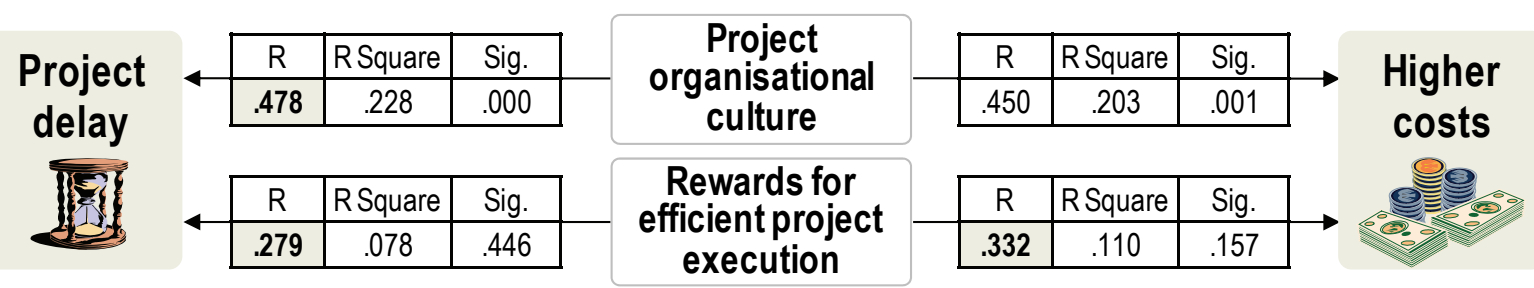

Based on the multivariate analysis of the survey data we can:

- fully support hypothesis 1: the behaviour and artefacts of project stakeholders increases the team members' motivation. The organisational culture has an impact on $50.5 \%$ of the team motivation with a correlation factor of $\rho=0.71$;

- partially support hypothesis 2: the analysis confirmed the first claim (monetary rewards for efficient project execution increase team motivation) with a positive correlation factor of $\rho=0.46$. The second claim "monetary rewards are a more important motivation factor than project organisational culture" was not supported. The organisational culture impacts on $50.5 \%$ of the team motivation, while monetary rewards only has an impact of $21.2 \%$;

- partially support hypothesis 3: the motivation of team members and project organisational culture directly provide for the more efficient execution of a project. Team motivation has an impact on $11.4 \%$ of project delay $(\rho=0.34)$ and $10.4 \%$ of cost overruns $(\rho=0.32)$, while project organisational culture impacts on $22.8 \%$ of project delay $(\rho=0.48)$ and $20.3 \%$ of cost overruns $(\rho=0.45)$. However, the analysis did not prove the significant direct impact of rewards.

The most reliable cultural variables of project performance proved to be clear priorities of projects (Sig. $=0.008$; a $0.8 \%$ possibility that the variable has no impact), top management attitude (.034) and respect of the project manager's formal authority (0.044). Top management's attitude has a significant impact on all other project organisational culture indicators (see the correlation factors in 
the appendix), indicating that the success of projects in the enterprise depends very much on the behaviour of executive managers.

The most reliable rewards were the reward for execution within budget (0.003), the percent of income (0.008) and a salary bonus for working on the project (0.058).

\section{Conclusions and suggestions for further research}

The research into the selected organisational cultural dimensions in Slovenian enterprises showed a high level of project organisational culture. This was relatively surprising in the context of the poor project performances (almost 90 percent of projects exceed the planned time and costs). The highest level proved to be top and line managements' attitude, while the most influential factors of project performance were top management's attitude and projects having clear priorities. The research also showed that in just $37 \%$ of Slovenian enterprises some kind of project rewards system was being implemented. The most used are a salary bonus for working on the project (13\%), a temporary higher salary for on time execution $(10 \%)$ and a temporary higher salary for execution within budget ( $8 \%)$.

The research confirmed our deliberation from the last paragraph of item 2.1.: low project organisational culture can cause project failure. Its direct impact proved to be even greater than team motivation! On the other hand, the absence of monetary rewards cannot cause project failure; yet this can have an impact on team motivation and consequently higher team performance.

The results of the research contribute to both science and practice in several ways. In the future, due to the ever greater number of projects, more stress should be placed on key project stakeholder behaviour and their relations, and organisational culture will become even more important. Once again it was proven that project organisational culture exerts a strong impact on project performance; even though we measured different cultural dimensions than most other recent researches.

An important contribution to science is the finding that top management's attitude also influences other cultural dimensions, especially line management's attitude and the level of following project management regulations. We believe that the culture has also an impact on many other areas, including the knowledge and behaviour of project managers, project planning and monitoring (the role of a sponsor), and resource allocation etc., which is a topic worthy of future research.

The findings of our research are especially useful for top and line managers in "transition countries" who have so far not been aware of how important their behaviour is for the success of projects conducted in their enterprises. Thus, we 
expect that our findings will significantly contribute to an understanding of work motivation theory and practice in the context of project management.

Top managers should give more attention to projects: they have to define proper project management regulations, promote the observance of those and the respect of the project manager's formal authority. They need to encourage and reward the active line managers' contributions to implementation of the project (staffing of professional and available people, technical support), and encourage trainings of project managers and other team members. They have to define clear priorities of projects and choose suitable project sponsors while, during project execution, they need to be interested in the project's status, and react in the case of any large deviations.

Even though the impact of rewards was not as high as the impact of the culture, project rewards contribute to team members' motivation. The results of our research in the area of rewards could be relatively tentative because of the limitations of the research: in the first place we did not examine the size of rewards (a higher benefit could have a bigger impact on motivation), then how the reward was distributed (the same share for all team members or different rewards for individuals), and the way the reward for particular members was defined. To clarify the impact of rewards we propose further research on the listed factors. In addition, rewarding during the execution of the project should be researched and compared with post-project rewarding.

To clarify the impact of the presented cultural dimensions we propose further research in two directions. The first should examine the dimensions in more detail - it should measure the individual factors presented in Table 1 (e.g. project monitoring, team recruitment, sponsor selection). More project success indicators (customer satisfaction, added value) could be added to those measured in our research (time, costs). In addition, researches only focussing on one type of project (IT, product development, civil engineering) could also yield useful findings. The second direction would involve researching the impact of the presented culture dimensions on team motivation in comparison with the leadership characteristics of project managers.

\section{References}

Andersen, E.S./Dysvik, A./Vaagaasar, A.L. (2009): Organizational rationality and project management, in: International Journal of Managing Projects in Business, 2, 4, 479-498.

Brown, C.J. (2008): A comprehensive organisational model for the effective management of project management, in: South African Journal of Business Management. 39, 3, 1-10.

Chang, K./Sheu T.S./Klein, G./Jiang, J.J. (2010): User commitment and collaboration: Motivational antecedents and project performance, in: Information and Software Technology, 52, 6, 672679.

Cleland, D.I. (1999): Project management: strategic design and implementation. New York: McGrawHill.

Davidson, J. (2000): 10 Minute Guide to Project Management. Indianapolis: Alpha Books. 
Doll, J.W. (1985): Avenues for Top Management Involvement in Successful MIS Development, in: MIS Quarterly. 9, 1, 17-35.

Dunn, S.C. (2001): Motivation by project and functional managers in matrix organizations, in: Engineering Management Journal, 13, 2, 3-9.

Dwivedula, R./ Bredillet, C.N. (2010): Profiling work motivation of project workers, in: International Journal of Project Management, 28, 2, 158-165.

Eskerod, P./ Skriver, H.J. (2007): Organizational Culture Restraining In-House Knowledge Transfer Between Project Managers - A Case Study, in: Project management Journal. 38, 1, 110-122.

Fister Gale, S. (2004): Cash on delivery, in: PM network, 59, 10, 58-62.

Fong, P.S.W./ Kwok, C.W.C. (2009): Organizational Culture and Knowledge Management Success at Project and Organizational Levels in Contracting Firms, in: Journal of Construction Engineering and Management. 135, 12, 1348-1356.

Forsberg, K./ Mooz, H./ Cotterman, H. (2005): Visualizing Project Management. Hoboken: John Wiley \& Sons.

Hars, A./ Ou, S. (2002): Working for Free? Motivations for Participating in Open-Source Projects, in: International Journal of Electronic Commerce, 6, 3, 25-39.

Heerkens, G.R. (2002): Project Management. New York: McGraw-Hill.

Kearns, G. (2007): How the internal environment impacts information systems project success: an investigation of exploitative and explorative firms, in: Journal of Computer Information Systems, 48, 1, 63-75.

Kerzner, H. (2001): Strategic planning for project management: using a project management maturity model. New York: John Wiley \& Sons.

Kerzner, H. (2009): Project management. Hoboken: John Wiley \& Sons.

Kerzner, H./ Saladis, F.P. (2009): What functional managers need to know about project management. Hoboken: John Wiley \& Sons.

Kuo, T.S./ Kuo, Y.L. (2010): The effect of corporate culture and total quality management on construction project performance in Taiwan, in: Total Quality Management. 21, 6, 617-632.

Levine, H.A. (2002): Practical project management: tips, tactics, and tools. New York: John Wiley \& Sons.

Lewis, J.P. (1995): Fundamentals of project management. New York: Amacom.

Lipičnik, B. (1993): Organizacija podjetja. Ljubljana: Ekonomska fakulteta.

Moore, C. (2002): Best Practices in Workflow. Giga Information Group, www.gigaweb.com.

Morrison, J.M./ Brown, C.J./ Smit, E. M. (2008): The impact of organizational culture on project management in matrix organizations, in: South African Journal of Business Management. 39, 4, 27-36.

National Defense University: Strategic Leadership and Decision Making, Organizational Culture, www.au.af.mil.

Peterson, T.M. (2007): Motivation: How to Increase Project Team Performance, in: Project Management Journal, 38, 4, 60-69.

Pinto, J.K. (2010): Project management: achieving competitive advantage. New Jersey: Prentice Hall.

PMI (1987): PMBOK - A guide to the project management body of knowledge. Newtown Square: Project management institute.

Rose, T./ Manley, K. (2010): Motivational misalignment on an iconic infrastructure project, in: Building Research \& Information, 38, 2, 144-156.

Rose, T./ Manley, K. (2011): Motivation toward financial incentive goals on construction projects, in: Journal of Business Research, 64, 7, 765-773. 
Sarin, S./ Mahajan, V. (2001): The Effect of Reward Structures on the Performance of CrossFunctional Product Development Teams, in: Journal of Marketing, 65, 2, 35-53.

Schmid, B./ Adams, J. (2008): Motivation in Project Management: The Project Manager's Perspective, in: Project Management Journal, 39, 2, 60-71.

Shore, B. (2008): Systematic Biases and Culture in Project Failures, in: Project Management Journal. $39,4,5-16$.

Simonsen, J. (2007): Involving top management in IT projects, in: Communications of the ACM. 50, $8,53-58$.

Snedaker, S. (2006): Syngress IT security project management handbook. Rockland: Syngress Publishing.

Škarabot, A., (1994): Moč in uspeh vodje projekta. Projektni management kot orodje za obvladovanje sprememb (zbornik posvetovanja). Ljubljana: Združenje za projektni management Slovenije. 113-122.

Taylor, T. (2010): The Challenge of Project Team Incentives. Compensation \& Benefits Review, 42, $5,411-419$.

Tinnirello, P.C. (2001): New Directions in Project Management. Boca Raton: Auerbach Publications.

Turk, W. (2008): Motivate Your People for Project Success. Defense AT\&L, 37, 4, 44-47.

Wideman, M. (2004): Wideman comparative glossary of project management terms v3.1. http://www.maxwideman.com/pmglossary/index.htm

Yazici, H.J. (2009): The Role of Project Management Maturity and Organizational Culture in Perceived Performance. Project Management Journal. 40, 3, 14-24.

Young, T.L. (2000): Successful project management. London: Kogan Page.

Young, R./ Jordan, E. (2008): Top management support: Mantra or necessity? International Journal of Project Management. 26, 6, 713-725.

\section{Appendix}

Table A: Correlation between the project culture indicators, team motivation and project performance

\begin{tabular}{|c|c|c|c|c|c|c|c|}
\hline & & $\begin{array}{l}\text { Team } \\
\text { moti- } \\
\text { vation }\end{array}$ & $\begin{array}{l}\text { Follow- } \\
\text { ing PM } \\
\text { regula- } \\
\text { tions }\end{array}$ & $\begin{array}{l}\text { Re- } \\
\text { specting } \\
\text { the PMI } \\
\text { autho- } \\
\text { rity }\end{array}$ & $\begin{array}{l}\text { Clear } \\
\text { prio- } \\
\text { rities of } \\
\text { pro- } \\
\text { jects }\end{array}$ & $\begin{array}{l}\text { Top } \\
\text { mngt. } \\
\text { atti- } \\
\text { tude }\end{array}$ & $\begin{array}{l}\text { Line } \\
\text { mngt. } \\
\text { atti- } \\
\text { tude }\end{array}$ \\
\hline \multirow[t]{3}{*}{ Project delay } & $\begin{array}{l}\text { Pearson } \\
\text { Correla- } \\
\text { tion }\end{array}$ & $-.342 * *$ & $-.290 * *$ & $-.297 * *$ & $-.403 * *$ & $-.291 * *$ & $-.245^{*}$ \\
\hline & $\begin{array}{l}\text { Sig. } \\
\text { (2-tailed) }\end{array}$ & .000 & .003 & .002 & .000 & .002 & .011 \\
\hline & $N$ & 107 & 100 & 104 & 107 & 107 & 107 \\
\hline
\end{tabular}




\begin{tabular}{|c|c|c|c|c|c|c|c|}
\hline \multirow[t]{3}{*}{ Cost overrun } & $\begin{array}{l}\text { Pearson } \\
\text { Correla- } \\
\text { tion }\end{array}$ & $-.315 * *$ & $-.248^{*}$ & $-.276 * *$ & $-.297 * *$ & $-.323 * *$ & $-.264 * *$ \\
\hline & $\begin{array}{l}\text { Sig. } \\
\text { (2-tailed) }\end{array}$ & .001 & .013 & .005 & .002 & .001 & .006 \\
\hline & $N$ & 107 & 100 & 104 & 107 & 107 & 107 \\
\hline \multirow[t]{3}{*}{ Team motivation } & $\begin{array}{l}\text { Pearson } \\
\text { Correla- } \\
\text { tion }\end{array}$ & & $.447^{* *}$ & $.549^{* *}$ & $.534^{* * *}$ & $.561^{* *}$ & $.529^{* * *}$ \\
\hline & $\begin{array}{l}\text { Sig. } \\
\text { (2-tailed) }\end{array}$ & & .000 & .000 & .000 & .000 & .000 \\
\hline & $N$ & & 104 & 109 & 112 & 112 & 111 \\
\hline \multirow[t]{3}{*}{$\begin{array}{l}\text { Following PM } \\
\text { regulations }\end{array}$} & $\begin{array}{l}\text { Pearson } \\
\text { Correla- } \\
\text { tion }\end{array}$ & & & $.563^{* *}$ & $.333^{* *}$ & $.331^{* *}$ & $.254^{* *}$ \\
\hline & $\begin{array}{l}\text { Sig. } \\
\text { (2-tailed) }\end{array}$ & & & .000 & .001 & .001 & .010 \\
\hline & $N$ & & & 102 & 104 & 104 & 103 \\
\hline \multirow[t]{3}{*}{$\begin{array}{l}\text { Respecting the } \\
\text { PM authority }\end{array}$} & $\begin{array}{l}\text { Pearson } \\
\text { Correla- } \\
\text { tion }\end{array}$ & & & & $.335^{* *}$ & $.500^{* *}$ & $.483^{* *}$ \\
\hline & $\begin{array}{l}\text { Sig. }(2- \\
\text { tailed) }\end{array}$ & & & & .000 & .000 & .000 \\
\hline & $N$ & & & & 109 & 109 & 108 \\
\hline \multirow[t]{3}{*}{$\begin{array}{l}\text { Clear priorities of } \\
\text { projects }\end{array}$} & $\begin{array}{l}\text { Pearson } \\
\text { Correla- } \\
\text { tion }\end{array}$ & & & & & $.527^{* *}$ & $.462^{* *}$ \\
\hline & $\begin{array}{l}\text { Sig. } \\
\text { (2-tailed) }\end{array}$ & & & & & .000 & .000 \\
\hline & $N$ & & & & & 112 & 111 \\
\hline \multirow[t]{3}{*}{$\begin{array}{l}\text { Top management } \\
\text { attitude }\end{array}$} & $\begin{array}{l}\text { Pearson } \\
\text { Correla- } \\
\text { tion }\end{array}$ & & & & & & $.657^{* *}$ \\
\hline & $\begin{array}{l}\text { Sig. } \\
\text { (2-tailed) }\end{array}$ & & & & & & .000 \\
\hline & $N$ & & & & & & 111 \\
\hline
\end{tabular}

** Correlation is significant at the 0.01 level (2-tailed) 
Table B: Correlation between the different types of rewards and team motivation

\begin{tabular}{|c|c|c|c|c|c|c|c|c|c|}
\hline & & $\mathbf{A}$ & B & $\mathbf{C}$ & D & $\mathbf{E}$ & $\mathbf{F}$ & $\mathbf{G}$ & $\mathbf{H}$ \\
\hline \multirow{3}{*}{$\begin{array}{l}\text { Team } \\
\text { motivation }\end{array}$} & $\begin{array}{l}\text { Pearson } \\
\text { Correlation }\end{array}$ & .342 & .264 & .131 & .032 & .367 & $.209^{*}$ & .094 & .287 \\
\hline & Sig. (2-tailed) & .000 & .005 & .167 & .738 & .000 & .027 & .326 & .002 \\
\hline & $N$ & 112 & 112 & 112 & 112 & 112 & 112 & 112 & 112 \\
\hline \multirow{3}{*}{$\begin{array}{l}\text { A) Implement- } \\
\text { ed rewards } \\
\text { (yes/no) }\end{array}$} & $\begin{array}{l}\text { Pearson } \\
\text { Correlation }\end{array}$ & & .548 & .412 & .304 & .509 & .306 & .343 & .324 \\
\hline & Sig. (2-tailed) & & .000 & .000 & .000 & .000 & .000 & .000 & .000 \\
\hline & $N$ & & 137 & 137 & 137 & 137 & 137 & 137 & 137 \\
\hline \multirow{3}{*}{$\begin{array}{l}\text { B) Reward for } \\
\text { execution in } \\
\text { time (yes/no) }\end{array}$} & $\begin{array}{l}\text { Pearson } \\
\text { Correlation }\end{array}$ & & & .687 & $.471_{* *}$ & .634 & .514 & .249 & $.196^{*}$ \\
\hline & Sig. (2-tailed) & & & .000 & .000 & .000 & .000 & .003 & .022 \\
\hline & $N$ & & & 137 & 137 & 137 & 137 & 137 & 137 \\
\hline \multirow{3}{*}{$\begin{array}{l}\text { C) Temporary } \\
\text { higher salary } \\
\text { for execution in } \\
\text { time }\end{array}$} & $\begin{array}{l}\text { Pearson } \\
\text { Correlation }\end{array}$ & & & & -.084 & .364 & .610 & -.095 & .105 \\
\hline & Sig. (2-tailed) & & & & .329 & .000 & .000 & .271 & .222 \\
\hline & $N$ & & & & 137 & 137 & 137 & 137 & 137 \\
\hline \multirow{3}{*}{$\begin{array}{l}\text { D) Lump sum } \\
\text { payment for } \\
\text { execution in } \\
\text { time }\end{array}$} & $\begin{array}{l}\text { Pearson } \\
\text { Correlation }\end{array}$ & & & & & & .041 & .648 &, 060 \\
\hline & Sig. (2-tailed) & & & & & .000 & .635 & .000 & .489 \\
\hline & $N$ & & & & & 137 & 137 & 137 & 137 \\
\hline \multirow{3}{*}{$\begin{array}{l}\text { E) Reward } \\
\text { for execution in } \\
\text { budget (yes/no) }\end{array}$} & $\begin{array}{l}\text { Pearson } \\
\text { Correlation }\end{array}$ & & & & & & & .550 & $.196^{*}$ \\
\hline & Sig. (2-tailed) & & & & & & .000 & .000 & .022 \\
\hline & $N$ & & & & & & 137 & 137 & 137 \\
\hline \multirow{3}{*}{$\begin{array}{l}\text { F) Reward } \\
\text { type: temporary } \\
\text { higher salary } \\
\text { for execution in } \\
\text { budget }\end{array}$} & $\begin{array}{l}\text { Pearson } \\
\text { Correlation }\end{array}$ & & & & & & & -.083 & .138 \\
\hline & Sig. (2-tailed) & & & & & & & .335 & .107 \\
\hline & $N$ & & & & & & & 137 & 137 \\
\hline \multirow{3}{*}{$\begin{array}{l}\text { G) Lump sum } \\
\text { payment for } \\
\text { execution in } \\
\text { budget }\end{array}$} & $\begin{array}{l}\text { Pearson } \\
\text { Correlation }\end{array}$ & & & & & & & & .039 \\
\hline & Sig. (2-tailed) & & & & & & & & .652 \\
\hline & $N$ & & & & & & & & 137 \\
\hline
\end{tabular}




\begin{tabular}{|ll|l|l|l|l|l|l|r|r|}
\hline H) Reward & Pearson \\
type: \% of & Correlation \\
project income & & & & & & & & $.213^{*}$ \\
& Sig. (2-tailed) & & & & & & & & \\
& $N$ & & & & & & & & .012 \\
& & & & & & & 137 \\
\hline
\end{tabular}

** Correlation is significant at the 0.01 level (2-tailed).

* Correlation is significant at the 0.05 level (2-tailed)

Table C: Impact of project organisational culture on team motivation - the regression of the variables

\begin{tabular}{|c|c|c|c|c|c|}
\hline \multirow[b]{2}{*}{ Model } & \multicolumn{2}{|c|}{$\begin{array}{l}\text { Unstandardized } \\
\text { Coefficients }\end{array}$} & \multirow{2}{*}{$\begin{array}{c}\begin{array}{c}\text { Stand. } \\
\text { Coefficients }\end{array} \\
\text { Beta }\end{array}$} & \multirow[b]{2}{*}{$\mathrm{t}$} & \multirow[b]{2}{*}{ Sig. } \\
\hline & B & Std. Error & & & \\
\hline (Constant) & -.001 & .362 & & -.004 & .997 \\
\hline Following PM regulations & .147 & .090 & .147 & 1.639 & .104 \\
\hline $\begin{array}{l}\text { Respecting the PM } \\
\text { authority }\end{array}$ & .202 & .099 & .206 & 2.042 & .044 \\
\hline Clear priorities of projects & .228 & .084 & .237 & 2.711 & .008 \\
\hline Top management attitude & .251 & .117 & .221 & 2.155 & .034 \\
\hline Line management attitude & .133 & .096 & .137 & 1.386 & .169 \\
\hline
\end{tabular}

a. Dependent Variable: Team motivation

Table D: Impact of rewards on team motivation - the regression of the variables

\begin{tabular}{|c|c|c|c|c|c|}
\hline \multirow[b]{2}{*}{ Model } & \multicolumn{2}{|c|}{$\begin{array}{l}\text { Unstandardized } \\
\text { Coefficients }\end{array}$} & \multirow{2}{*}{$\frac{\begin{array}{c}\text { Standard. } \\
\text { Coefficients }\end{array}}{\text { Beta }}$} & \multirow[b]{2}{*}{$\mathrm{t}$} & \multirow[b]{2}{*}{ Sig. } \\
\hline & B & Std. Error & & & \\
\hline (Constant) & 3.047 & .117 & & 26,028 & .000 \\
\hline $\begin{array}{l}\text { Reward for execution } \\
\text { in time }\end{array}$ & -.022 & .318 & -.008 & -.069 & .945 \\
\hline $\begin{array}{l}\text { Reward for execution } \\
\text { in budget }\end{array}$ & .988 & .329 & .361 & 3.005 & .003 \\
\hline $\begin{array}{l}\text { Reward type: } \% \text { of } \\
\text { project income }\end{array}$ & 1.038 & .383 & .246 & 2.714 & .008 \\
\hline $\begin{array}{l}\text { Rewarded work on the } \\
\text { project }\end{array}$ & .519 & .272 & .167 & 1.913 & .058 \\
\hline
\end{tabular}

a. Dependent Variable: Team motivation 
Table E: Impact of team motivation on project delay

\begin{tabular}{|l|r|r|r|r|r|}
\hline \multirow{2}{*}{ Model } & \multicolumn{2}{|c|}{$\begin{array}{c}\text { Unstandardized } \\
\text { Coefficients }\end{array}$} & \multicolumn{1}{c|}{$\begin{array}{c}\text { Stand. } \\
\text { Coefficients }\end{array}$} & \multirow{2}{*}{ t } & \multicolumn{1}{|c|}{ Sig. } \\
\cline { 2 - 4 } & \multicolumn{1}{|c|}{ B } & Std. Error & \multicolumn{1}{|c|}{ Beta } & 7.187 & .000 \\
(Constant) & 42.554 & 5.921 & & -3.661 & .000 \\
\hline
\end{tabular}

a. Dependent Variable: Project delay

Table F: Impact of team motivation on cost overrun

\begin{tabular}{|l|r|r|r|r|r|}
\hline \multirow{2}{*}{ Model } & \multicolumn{2}{|c|}{$\begin{array}{c}\text { Unstandardized } \\
\text { Coefficients }\end{array}$} & \multicolumn{1}{c|}{$\begin{array}{c}\text { Stand. } \\
\text { Coefficients }\end{array}$} & \multirow{2}{*}{ t } & \multicolumn{1}{|c|}{ Sig. } \\
\cline { 2 - 4 } & \multicolumn{1}{c|}{$\mathrm{B}$} & Std. Error & Beta & 6.745 & .000 \\
(Constant) & 29.108 & 4.315 & & -3.483 & .001 \\
\hline
\end{tabular}

a. Dependent Variable: Cost overrun 